\title{
新規有機顔料の開発と特性について
}

\author{
日本ゼオン株式会社 任田英樹，前田大晴，片岡靖男
}

\section{Development and Characteristic of Novel Plastic Pigments}

\author{
Hideki Toda, Daiharu Maeda and Yasuo Kataoka \\ NIPPON ZEON CO., LTD.
}

We have developed various novel plastic pigments. They are especially for coated paper and paper board. The coated paper and paper board containing plastic pigment instead of inorganic pigment have high gloss, brightness and opacity.

In this report, characteristic of binder-type and hollow sphere plastic pigments which have lately been attracted considerable attention will be discussed.

Binder-pigment type latex has dual functions of a pigment and a binder. Accordingly, it is possible to reduce the amount of the conventional binder latex. It is able to used for high grade coated paper and paper board. Nobel hollow sphere plastic pigment which is prepared by alkali/ acid treatments of carboxylated polymer particles has high opacity and sheet gloss of coatings.

It's smaller specific gravity leads to lighter weight coated paper.

\section{1.はじめに}

最近の印刷用新の需要動向としては 2 極分化現象が 起きている。一つは, 印刷物の轻量指向であり，もう 一方はスーパーアート紙に代表される高級化指向であ る。

これらの動向に対応し各種塗工原材料の改良開発が 進められており，その中で特に開発が著しいものは有 機顔料である。それは，有機顔料を使用することによ ク光学的性質の向上が著しいことと, 無機顔料と比較 して比重が低い為に印刷適正を保持したまま紙の軽量 化か図られることに由来する。

そこで本報告では，有機顔料の中でも注目を集めて いるパインターピクメントラテックス・中空粒子等の 新規有機顔料の特性について報告する。

\section{2. 有機顔料の設計}

\section{1 パインターピグメトラテックス}

(Nipol LX 407 BP)

有機顔料は優れた特性を付与する顔料であるが，価 格が通常の無機顔料より大幅に高い為にその使用が制 限されているのか実状である。パインターピクメント ラテックスはこのコスト上の閣題を柽隇することを狙 いとして開発された粒子自身がパインター機能を併有
する有機顔料である。

日本ゼオンより上市しているパインターピクメント ラテックス (Nipol LX 407 BP) は図1に示した様な 2 層構造である。核 (コア) 部はポリスチレンで構成 され有機顔料の性質を示し, 殼 (シェル) 部は通常の パインターラテックスと同様のスチレン・ブタジエン 共重合体から構成されているため接着機能を発現する。 この 2 層構造は透過型電子顕微鏡写真でも容易に観察 することができる。写真 1 の粒子内部の黒く染色され た部分が殸部のスチレン・ブタジン共重合体部分で ある。また, カララス転移温度を测定すると $0^{\circ} \mathrm{C}$ と $100^{\circ} \mathrm{C}$

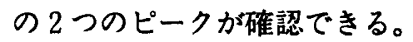

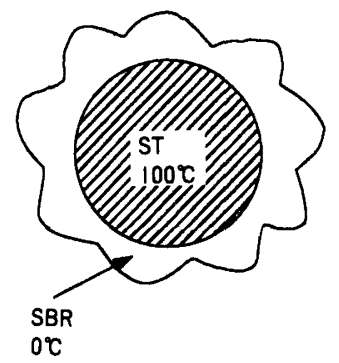

図 1 パインターピクメントラテックスの粒子構造 モデル 
表 1 パインダーピグメントラテックスの性質

\begin{tabular}{l|c}
\hline \multicolumn{2}{c}{ LX 407 BP の性質 } \\
\hline 固形分濃度 & $50 \%$ \\
粒子径 & $350 \mathrm{~nm}$ \\
$\mathrm{pH}$ & 7.5 \\
B 型粘度 & $30 \mathrm{cps}$ \\
ガラス転移温度 & $0 \& 100^{\circ} \mathrm{C}$ \\
成膜温度 & $30^{\circ} \mathrm{C}$ \\
\hline
\end{tabular}

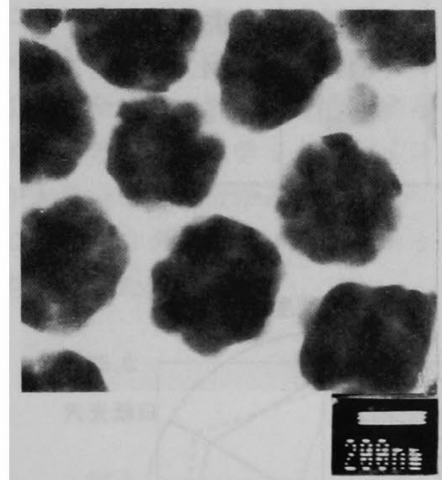

写真 1 パインターピクメント ラテックスの電子顕微 鏡写真

\section{2 高空㭞型中空粒子 (MH)}

乳化重合を応用することにより 2 層構造以外にも 様々な形態の粒子を設計することが可能であり，その 典型が中空粒子である。我々も独自の技術にて中空粒 子を作成し開発を進めてきた。その手法を图 2 に示す。 これは粒子内部のカルボキシ変性された分子鎖を塩 基・酸 2 段階処理にて移動させることにより中空構造 に移行させる技術である。

塩基・酸 2 段階処理により作成した中空粒子の特性 は, 従来の方法と比較して高空陌率が得られることが 特徴である。以下に高空隚型中空粒子の特性について
表 2 機能性中空粒子の性質

\begin{tabular}{l|c|c}
\hline \multicolumn{2}{l|}{} & MH \\
\hline 粒子径 & $\mathrm{nm}$ & 500 \\
孔 径 & $\mathrm{nm}$ & 410 \\
空隙率 & $\%$ & 55 \\
特 徴 & & 高空隚型 \\
\hline
\end{tabular}

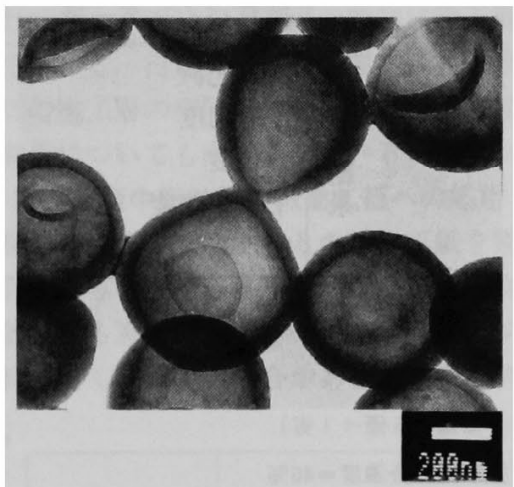

写真 2 透過型電子顕微鏡写真

表 2 に示す。

また，その透過型電子顕微鏡写真を写真 2 に示す。

\section{3 中空粒子の機能化}

塩基・酸 2 段階処理により作成した中空粒子のもう 一つの特性として, 水分散状態においても既に中空構 造に変化している為, 様々な形態に粒子を修飾するこ とが可能となる。

例えば，バインダーピグメントの特徵を採り入れた, バインダー機能保有型中空粒子や耐熱性や耐溶剤性を 持つ高機能性中空粒子への修飾が可能である。

\section{3. 塣工紙用への展開}

\section{1 パインターピクメントラテックスの塗エ紙 への応用}

カオリナイトクレイ単独配合 $(\mathrm{A})$, プラスチックピ

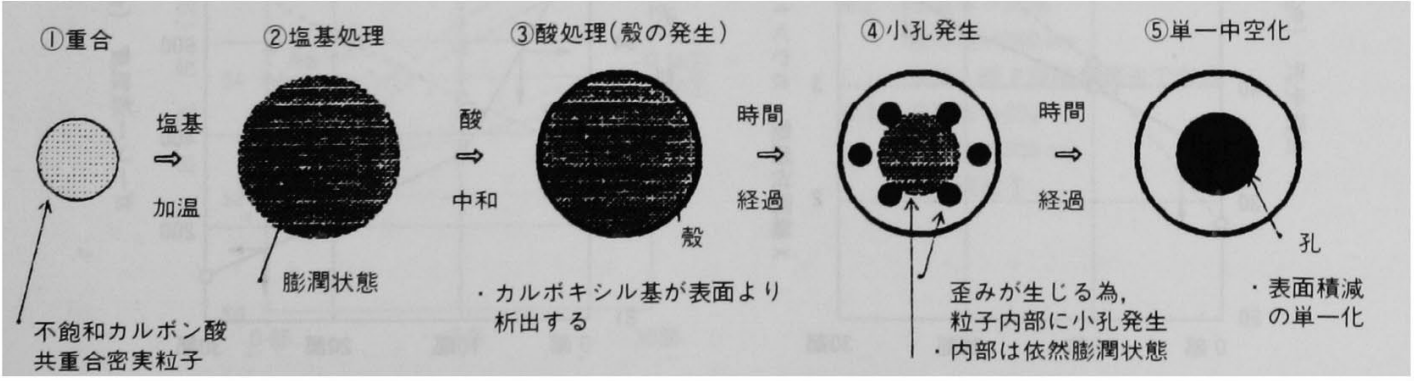

図 2 塩基・酸 2 段階処理法 
表 3 バインダーピグメントラテックスの配合例

\begin{tabular}{|c|c|c|c|c|c|}
\hline & & & A & B & $\mathrm{C}$ \\
\hline \multirow{3}{*}{ 配 } & \multicolumn{2}{|l|}{1 級クレイ } & 100 & 70 & 70 \\
\hline & \multicolumn{2}{|c|}{ プラスチックピグメント } & 0 & 30 & 0 \\
\hline & \multicolumn{2}{|c|}{ バインターピグメントラテックス } & 0 & 0 & 30 \\
\hline \multirow[t]{3}{*}{ 合 } & \multicolumn{2}{|c|}{ カゼイン } & 9 & 9 & 9 \\
\hline & \multicolumn{2}{|c|}{ ラテックス（LX 407 F 8) } & 13 & 14 & 0 \\
\hline & \multicolumn{2}{|c|}{ 換算バインター量 } & 22 & 23 & 24 \\
\hline \multirow{5}{*}{$\begin{array}{l}\text { 評 } \\
\text { 価 } \\
\text { 結 } \\
\text { 果 }\end{array}$} & 白紙光沢 & $(\%)$ & 29 & 62 & 58 \\
\hline & 不透明度 & $(\%)$ & 92.3 & 93.4 & 93.8 \\
\hline & 白色度 & (\%) & 82.3 & 84.7 & 84.8 \\
\hline & ドライ強度 & （ 5 点法） & 5.0 & 5.0 & 5.0 \\
\hline & 吸水着肉性 & （ 5 点法） & 2.2 & 3.4 & 4.3 \\
\hline
\end{tabular}

5 点法 ( 5 優 $\Rightarrow 1$ 劣)

\section{等工固形分浱度 $=46 \%$}

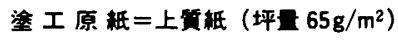

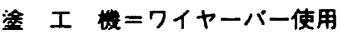

乾燥温度 $=100^{\circ} \mathrm{C} ; 20$ 秒

工 $\mathrm{I}=$ 約 $10 \mathrm{~g} / \mathrm{m}^{2}$ (片面)

拥温知湿=温度 $20{ }^{\circ} \mathrm{C} \cdot$ 湿度 $65 \%$
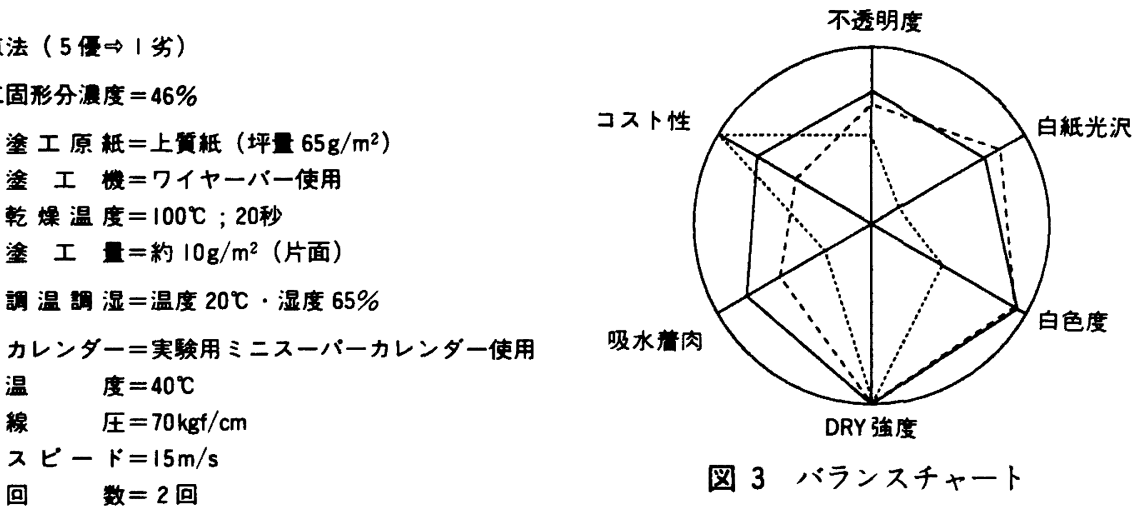

図 3 バランスチャート

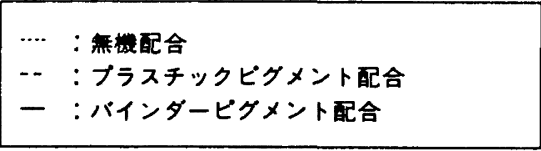

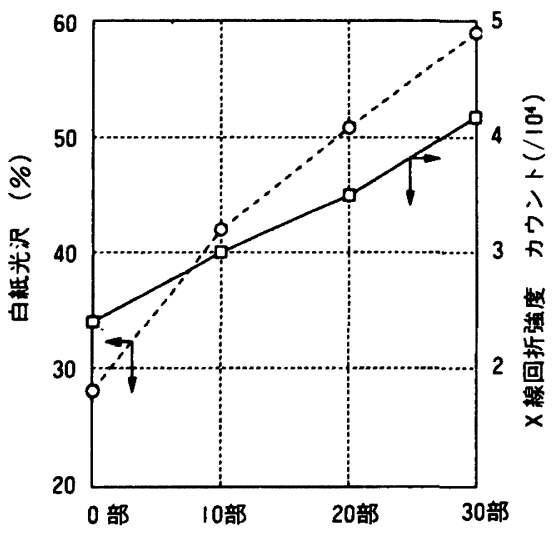

图 4 白紙光沢と $\mathrm{X}$ 線回折強度

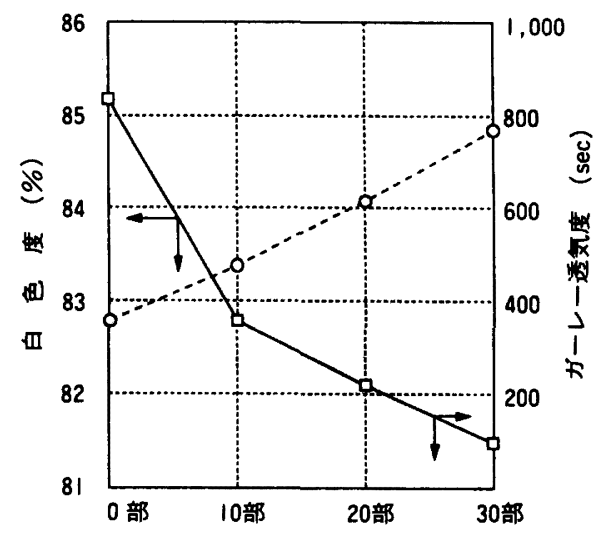

図 5 白色度とガーレー透気度 
クメント配合 $(\mathrm{B})$ ，パインターピクメントラテックス の配合を（C）とした時の配合例と物性值を表 3 に示 した。

釷工紙の高級感を出すためにプラスチックピクメン トを使用するが, 無機顔料のみと比較するとコスト アップにつながる。しかし，パインターピクメントラ テックスを使用することにより塗工紙物性を維持しパ インターラテックスが減量できる為，コスト上昇を抑 えることが可能となる(この場合 13 部 $\Rightarrow 0$ 部)。図 3 ではこれらの塗工紙のバランスチャートを示した。光 学的性質に関してはプラスチックピクメント，ハイン ターピクメントラテックスが共に良くなっている。し かし, 塗工紙の全体のコスト性を考虑すると, パイン ターピクメントの場合, ラテックスパインターを減量 する効果が大きいことが分かる。

図 4,5にはバインターピクメントラテックスの配合 量の影響を確認した。

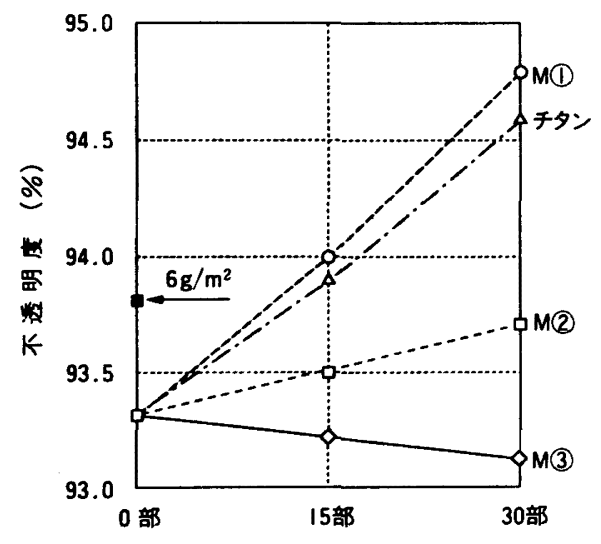

図 6 配合代替部数と不透明度

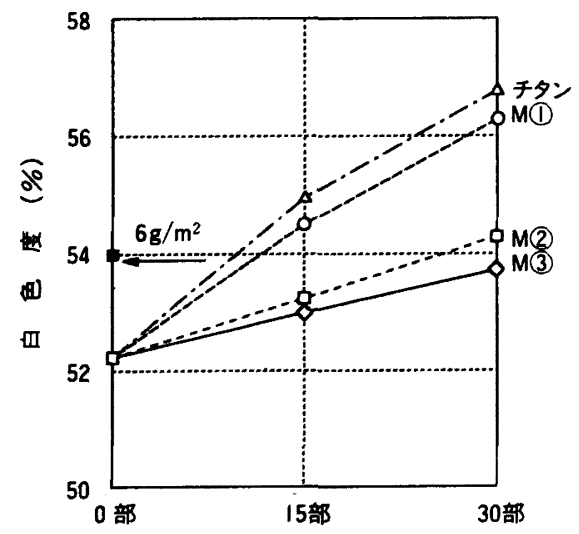

図 8 配合代替部数と白色度
图4 にはバインターピクメントラテックスの配合量 と白紙光沢のグラフにX線回折強度のグラフを合わせ た。X線回折強度の增加はクレイの配向性を示してお ク，つまりパインターピクメントラテックスの增量は, X線回折強度より推察するとクレイの配向性を向上さ せ，それが白紙光沢の向上にも寄与していることが推 察できる。図 5 ではバインターピクメントラテックス の配合量と白色度の関係に, カーレー透気度の測定結 果を合わせた。ガーレー透気度の增加は染工層の空隙 の增大を意味し，白色度に影響していると推察できる。 また，この染工首の空陌の增加はインキ受理性にも影 響し着肉性についても向上させている。

\section{2 高空除型中空粒子の微汪工紙への応用}

印刷物の柽量化で問題となるのは垐工紙を両面印刷 した場合の袁写り性である。これは軽量化の為に不透 明度が低下する為である。そこで，酸化チタン等の高 隐蔽顔料を多く使用する場合があるが無機顔料では限

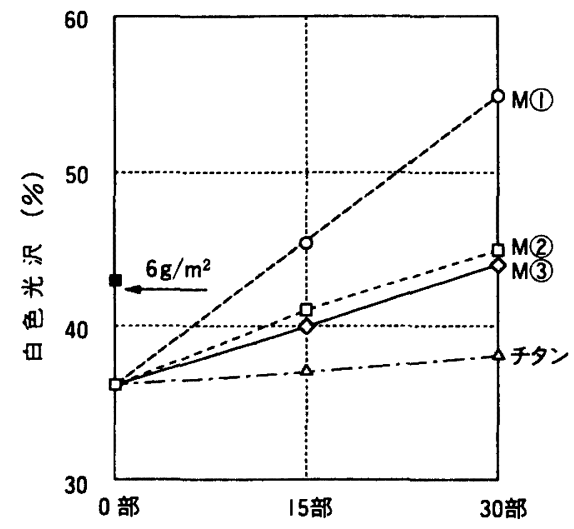

図 7 配合代替部数と光沢

注） M(1)：空除率 $=55 \%$

粒子径 $=500 \mathrm{~nm}$

塩基・酸 2 段階好理法で作成

M(2) : 空除率 $=27 \%$

粒子径 $=500 \mathrm{~nm}$

塩基・酸 2 段階処理法で作成

M(3) : 空除率 $=0 \%$

粒子径 $=500 \mathrm{~nm}$

未処理粒子 
界があり，有機顔料系中空粒子が検討されてきた。

これは中空粒子内部の孔による高い光散乱効果を利 用したものである。

ここでの報告は，中質原紙(坪量 $\left.48 \mathrm{~g} / \mathrm{m}^{2}\right)$ に $3 \mathrm{~g} / \mathrm{m}^{2}$ 塗工した場合の塗工紙の評価を行ったものである。な お塗工紙作成条件については後記の方法によった。

先ず 3 種類の空陌率の異なる $(55 \%, 27 \%, 0 \%)$ 有 機顔料について配合代替部数と不透明度 - 光沢 - 白色 度に与える効果を测定した。不透明度に関しては，空 腺率と相関が最も強く高空吵率のものが高鿵蔽性顔料 の酸化チタンと同等である。更に光沢に関しても $55 \%$ と空隙率が高いものが無機のみの配合と比較すると約 $20 \%$ 高い値を示している。白色度に関しては，酸化 チタンよりやや劣るものの空隚率 $55 \%$ のものは高い 值を示している。図6〜8に示した日印はモデル配合で $6 \mathrm{~g} / \mathrm{m}^{2}$ 染工した場合の染工紙の評価結果である。これ と比較すると澵工量を半減 $\left(3 \mathrm{~g} / \mathrm{m}^{2}\right)$ しても，15 部程 度高空陌型中空粒子を使用すれば同等の染工紙物性か 得られることが分かる。

塗工条件

(1) 配 合

\section{䫏料/接着骩 $=100 / 16$}

顔

$$
\begin{aligned}
\text { 料 } & =\mathrm{UW}-90 / \text { Carbital }-90 / \mathrm{MH} \text { シリース } \\
& =70 / 30 / 0=61 / 24 / 15=49 / 21 / 30
\end{aligned}
$$

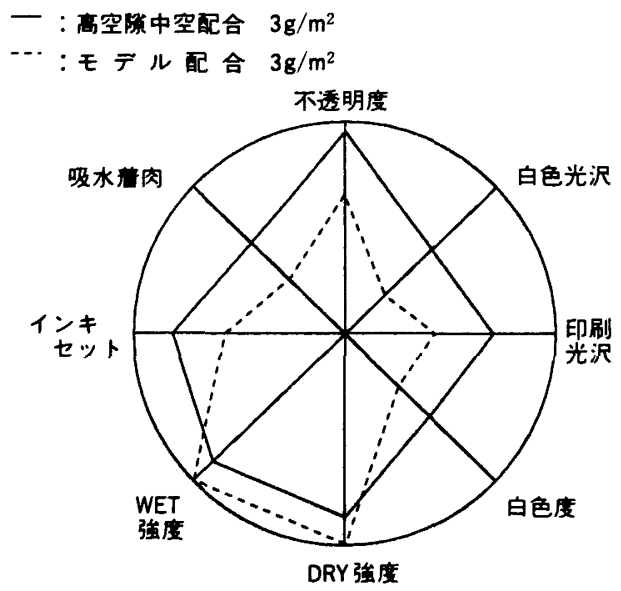

图 9 染工紙物性のバランス(1)
接 着 郕 $=$ MS $4600 / \mathrm{Nipol} \mathrm{LX} 407$ F 8 $=3 / 13$

分 散 郕=アロン $\mathrm{T}-40 \quad 0.25 \%$ on Pigment

滑 剂 $=\mathrm{C}-104 \quad 0.5 \%$ on Pigment

$\mathrm{pH}$ 調整郕 $=\mathrm{NaOH} 0.15 \%$ on Pigment

(2) 塗 工

固形分濃度 $=46 \%$

塗工原 紙=中質紙 (坪量 $\left.48 \mathrm{~g} / \mathrm{m}^{2}\right)$

塗 エ 機二卓上型手動フレードコーター (フレー ド圧；2.0 kg)

塗 工 量=約 $3 \mathrm{~g} / \mathrm{m}^{2}$ (片面)/モデル配合のみ約 6 $\mathrm{g} / \mathrm{m}^{2}$ (片面) 已作成

(3) 乾 燥

乾燥 温度 $=100^{\circ} \mathrm{C} ; 20$ 秒

(4) 調温調湿

温度 $20^{\circ} \mathrm{C} \cdot$ 湿度 $65 \%$

(5)カレンター(実験用ミニスーパーカレンター使用)

温 度 $=60^{\circ} \mathrm{C}$

線 圧 $=70 \mathrm{kfg} / \mathrm{cm}$

スピード $=15 \mathrm{~m} / \mathrm{S}$

回 数 $=2$ 回

ここで，光学的性質以外に要求される塗工紙物性に ついてバランスチャートを図 9，10に示した。図９は 高空隙型中空配合とモデル配合の比較である。強度以 外において全ての点で印刷適性が優った。また図 10 に

一 : 高空隐中空配合 $3 \mathrm{~g} / \mathrm{m}^{2}$
一・ : モ デル 配 合 $6 \mathrm{~g} / \mathrm{m}^{2}$

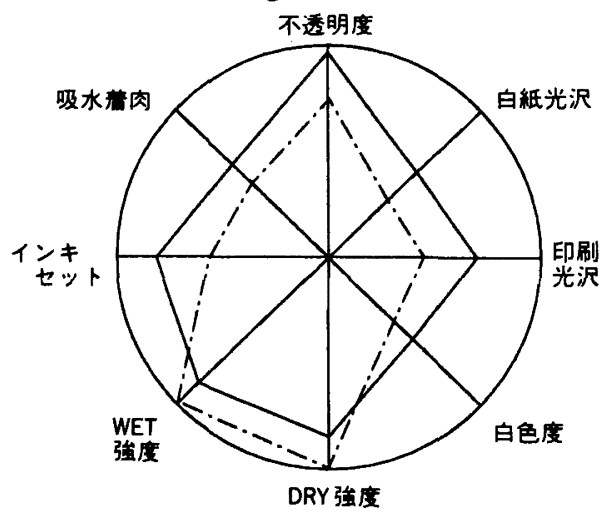

\begin{tabular}{|c|c|c|c|c|c|c|c|c|c|}
\hline \multicolumn{2}{|c|}{$\begin{array}{c}\text { バランスチャート } \\
\text { 設定値 }\end{array}$} & $\begin{array}{c}\text { 不 透 } \\
\text { 明 度 } \\
\%\end{array}$ & $\begin{array}{c}\text { 白 紙 } \\
\text { 光 沢 } \\
\%\end{array}$ & $\begin{array}{c}\text { 印 刷 } \\
\text { 光 沢 } \\
\%\end{array}$ & 白色度 & $\begin{array}{l}\text { DRY } \\
\text { 胎 度 } \\
5 \text { 点 }\end{array}$ & $\begin{array}{l}\text { WET } \\
\text { 強 度 } \\
5 \text { 点 }\end{array}$ & $\begin{array}{l}\text { インキ } \\
\text { セット } \\
\text { 漂度 }\end{array}$ & $\begin{array}{ll}\text { 吸 } & \text { 水 } \\
\text { 䒚 } & \text { 肉 } \\
\text { 流 } & \text { 度 }\end{array}$ \\
\hline 下 限 值 & 円中心值 & 90.0 & 20.0 & 40.0 & 45.0 & 1.0 & 1.0 & 50 & 0.5 \\
\hline 上限 值 & 円 周 值 & 95.0 & 80.0 & 90.0 & 65.0 & 5.0 & 5.0 & 20 & 1.5 \\
\hline
\end{tabular}

図10 塗工紙物性のバランス(2) 
はモデル配合の㓌工量を倍にしても 30 部, 中空粒子を 全体で代替した場合は印刷適正に優れることが示され た。中空粒子を使用することにより塗工量を半減して も同等以上の印刷適性が発現されることは, 染工紙の 軽量化と低コスト化の両方の点で有利であると推察で きる。

この様に中空粒子を用いることによる光学的性質, 印刷適性が向上する要因であるが, 中空粒子の低密度 からくる耑高さによるところが大きいこの実証とし て塗工後 (カレンター処理前) の塗工層の平滑性及び, カレンター処理後の塗工層の平滑性がかなり異なるこ とが図11より分かる。嵩高さが原紙の凹凸をカパーし 平滑性が增しているため光学的性質, 印刷適性が向上 すると考えられる。

これは, 写真 3 のカレンター処理後の塗工層表面の

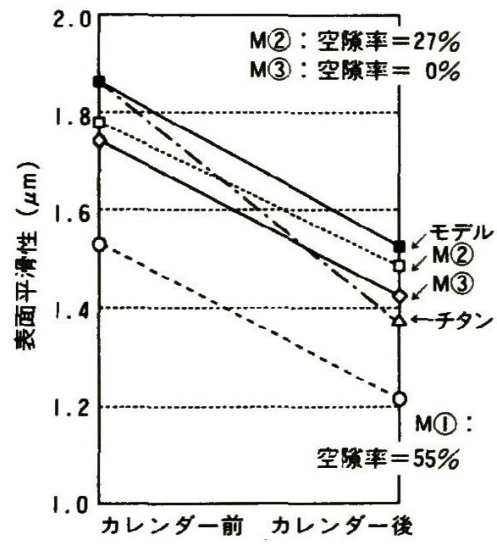

図 11 カレンター前後の平滑性

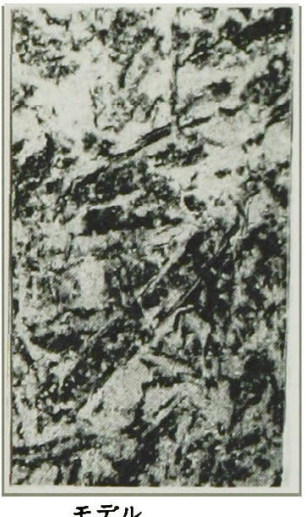

モテ゚ル

慗工量 $3 \mathrm{~g} / \mathrm{m}^{2}$

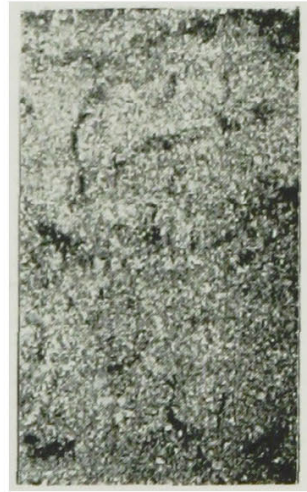

高空陸型中空顔料

量 $3 \mathrm{~g} / \mathrm{m}^{2}$
写真 3 染工層表面の走查型電子顕徽鏡 2 次 電子像

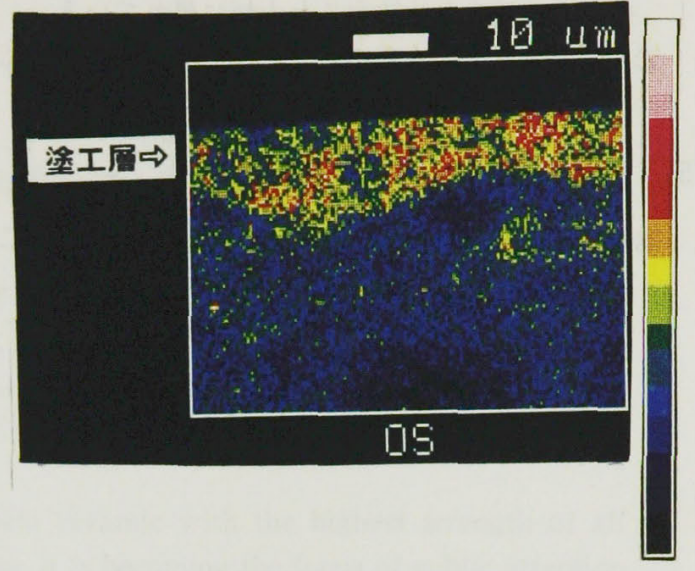

写真 4 中空粒子の塗工層 Z 軸方向の分布

走査型電子顕微鏡 2 次電子像にも衰付けされる。無機 顔料のみのモデル配合では $3 \mathrm{~g} / \mathrm{m}^{2}$ 塗工しても下部の 原紙層が表面に現れているが，同じ $3 \mathrm{~g} / \mathrm{m}^{2}$ 塗工でも 高空隙型中空顔料を使用した場合, 原紙を完全に被覆 していることが観察できる。

次に中空顔料を用いた場合の塗工層 Z 軸方向の分布 について EPMA (Electron Probe Micro Analyzer) により解析した結果を写真 4 に示す。これは, 中空粒 子のみを染色し分布を明確にしたものである。

この結果より，中空粒子の場合においては特に準工 層におけるZ軸方向の分布は無く, 非常に均一な状態 で分布していることが観察された。

従って中空粒子を使用した場合の印刷適性及び光学 的性質の向上は, 中空粒子が特に塗工層表面に多く分 布しカレンター効果を受けやすい為では無く, 塗工層 の嵩高さによるものであると推察できる。

4. まと め

(1) パインターピクメントラテックスを使用するこ とにより。

(1) 通常の無機顔料やプラスチックピグメントを使 用する場合と比較すると通常のバインターを減量 あるいは未使用でも同等の強度が発現される。

(2) ハインターを減量しても, 光学的性質及び印刷 適性は無機顔料のみと比較すると向上する。また プラスチックピクメントと比較すると同程度であ る。

（2）高空隙型中空粒子は塗工紙に使用することによ $\eta$,

(1) 不透明度, 白色度で酸化チタン白に近い性能を 有し, 従来のプラスチックピクメントや空陌率の 
低い中空粒子と比較すると大幅に優れている。

(2) 印刷光沢, 吸水着肉などの印刷適性も従来のも のと比較すると優れた性能を発現する。
とは明白である。また塗工紙分野以外でも様々な分野 で応用され，今後，バインター型・耐熱型・耐溶剤型 に止まらず機能性の中空粒子が開発されるであろう。

5. 今後の動向

高級䄪・軽量紙に今後中空粒子の需要が拡大するこ 